WRITING FOR SCIENCE 



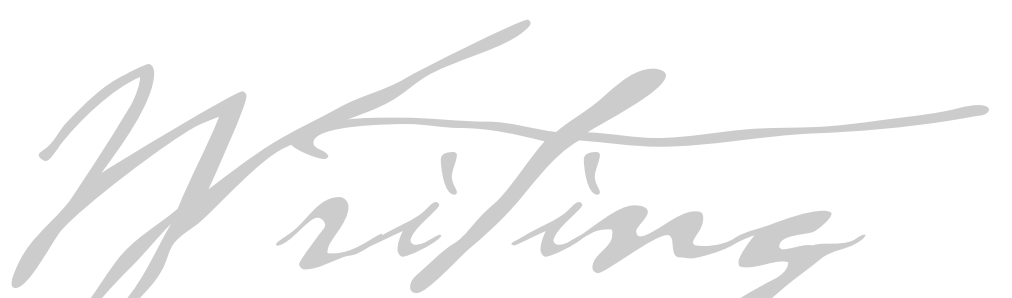

\section{FOR SCIENCE}

Robert Goldbort

Yale University Press

New Haven \& London 
Copyright (C) 2006 by Yale University. All rights reserved.

This book may not be reproduced, in whole or in part, including illustrations, in any form (beyond that copying permitted by Sections 107 and 108 of the US Copyright Law and except by reviewers for the public press),

without written permission from the publishers.

Designed by Nancy Ovedovitz and set in Times Roman type by The Composing Room of Michigan, Inc. Printed in the

United States of America by Vail-Ballou Press, Binghamton, New York.

\section{Library of Congress Cataloging-in-Publication Data}

Writing for science / Robert Goldbort, 1949_

p. $\mathrm{cm}$.

Includes bibliographical references and index.

ISBN-13: 978-0-300-11551-2 (cloth : alk. paper)

ISBN-10: 0-300-11551-2 (cloth : alk. paper)

ISBN-13: 978-0-300-11793-6 (pbk. : alk. paper)

ISBN-10: 0-300-11793-0 (pbk. : alk. paper)

1. Technical writing. 2. Communication in science.

I. Title.

$$
\begin{array}{rl}
\text { T11.G626 } & 2006 \\
808^{\prime} .0665-\mathrm{dc} 22 & 2006012742
\end{array}
$$

A catalogue record for this book is available from the British Library.

The paper in this book meets the guidelines for permanence and durability of the Committee on Production Guidelines for Book Longevity of the Council on Library Resources. 
To Joanne

and to our treasures

Raechel, Jonathan, Julia, Sarah 
